\title{
Fabrication and Degradation of Electrospun Polyhydroxyalkanoate Film
}

\author{
Lee Joyyia, \\ Nanthini Sridewi ${ }^{b}$, Amirul Al-Ashraf Abdullaha, \\ Ken-ichi Kasuya ${ }^{c}$ and Kumar Sudesh ${ }^{\text {a* }}$ \\ ${ }^{a}$ School of Biological Sciences \\ University Sains Malaysia \\ Penang, 11800, Malaysia \\ ${ }^{b}$ National Defence University of Malaysia \\ Kuala Lumpur, 57000, Malaysia \\ ${ }^{c}$ Division of Molecular Science \\ Gunma University \\ 1-5-1 Tenjin, Kiryu, Gunma 376-8515, Japan
}

Received 19.01.2015, received in revised form 20.02.2015, accepted 16.05.2015

Polyhydroxyalkanoates (PHAs) are a family of biopolymers with good biodegradability. Poly(3hydroxybutyrate) $[P(3 H B)]$, poly(3-hydroxybutyrate-co-25 mol \% 4-hydroxybutyrate) [P(3HBco-25 mol \% 4HB)] and poly(3-hydroxybutyrate-co-75 mol \% 4-hydroxybutyrate) [P(3HB-co-75 mol\% $4 H B)]$ were fabricated using the electrospinning technique to obtain fibers. Electrospun $P(3 H B)$ showed formation of fibers when $30 \mathrm{kV}$ voltage was applied to $4 \% \mathrm{P}(3 \mathrm{HB})$ extruded at $60 \mu \mathrm{L} / \mathrm{min}$ with prior heating for 15 min at $60{ }^{\circ} \mathrm{C}$. Fabricated $\mathrm{P}(3 \mathrm{HB}-\mathrm{co}-4 \mathrm{HB})$ showed a continuous polymer mat with embedded beads formation. $P(3 H B)$ fabricated at different time of electrospinning $(5,10,15$ and $20 \mathrm{~min})$ and concentrations (1\%,2 \%, $3 \%$ and $4 \%$ ) subjected to in vitro enzymatic degradation by PHA depolymerase showed decrease in polymer weight. The highest rate of degradation was exhibited by $2 \%$ P (3HB) electrospun for $15 \mathrm{~min}$. Films of $1 \% \mathrm{P}(3 \mathrm{HB}-\mathrm{co}-25 \mathrm{~mol} \% 4 \mathrm{HB})$ and $1 \% \mathrm{P}(3 \mathrm{HB}-$ co-75 mol \% 4HB) subjected to in vitro lipase degradation also exhibited decrease in polymer weight. $P(3 H B-c o-75 \mathrm{~mol} \% 4 H B)$ films showed significant decrease in weight compared to P(3HB-co-25 mol \% 4HB). Degraded P(3HB) had fibril-like structures whereas $P(3 H B-c o-4 H B)$ surface structure became more porous. Environmental degradation of these polymers was successful with $\mathrm{P}(3 \mathrm{HB}-\mathrm{co}-$ $4 H B)$ being better degraded.

Keywords: polyhydroxyalkanoates, biopolymers, electrospinning, in vitro, degradation.

DOI: $10.17516 / 1997-1389-2015-8-2-236-253$.

(c) Siberian Federal University. All rights reserved

* Corresponding author E-mail address: ksudesh@usm.my 


\title{
Изготовление и деградация пленок \\ из электроспряденного полигидроксиалканоата
}

\author{
Ли Джойи ${ }^{\mathbf{a}}$ Нантини Сридеви \\ Амирул Аль-Ашраф Абдулла', \\ Кен-ичи Касуйя ${ }^{\text {, }}$ \\ ${ }^{a}$ Школа биологических наук \\ Университет науки Малайзии \\ 11800, Пенанг, Малайзия \\ ${ }^{6}$ Национальный университет обороны Малайзии \\ 57000 Куала-Лумпур, Малайзия \\ ${ }^{\circ}$ Университет Гуммьл \\ 1-5-1 Тенджин, Кирю, Гумма 376-8515, Япония
}

Полигидроксиалканоаты (ПГА) представляют собой семейство биополимеров с хорошей биоразлагаемостью. С использованием электростатического формования были получены пленки из волокон поли-3-гидроксибутирата [П(ЗГБ)], поли-3-гидроксибутирата-со-4гидроксибутирата с содержанием 25 молярных \% 4ГБ [П(ЗГБ-со-25 мол. \% 4ГБ)] и поли-3гидроксибутирата-со-4-гидроксибутирата с содержанием 75 мол. \% 4-гидроксибутирата [П(ЗГБ-со-75 мол. \% 4ГБ)]. Электростатическое формование П(ЗГБ) после предварительного нагрева в течение 15 минут при температуре $60{ }^{\circ} \mathrm{C}$ продемонстрировало формирование волокон при воздействии напряжения 30 кВ на 4\%-ный раствор П(ЗГБ) при скорости подачи раствора 60мкл/мин. Полученный П(ЗГБ-со-4ГБ) представлял собойнепрерывныйполимерный мат с вкрапленными гранулами. П(ЗГБ), спряденный при различной продолжительности электростатического формования (5, 10, 15 и 20 мин) и при разной концентрации растворов (1, 2, 3 и 4\%), подвергнутый ферментативной деградаџии in vitro с использованием ПГАдеполимеразы, показал уменьшение массы полимера. Наибольшая скорость деградации была достигнута при электроформовании $2 \%$ П(ЗГБ) в течение 15 минут. У пленок из 1 \% П(ЗГБсо-25 мол. \% 4ГБ) и $1 \%$ П(ЗГБ-со-75 мол. \% 4ГБ), подвергнутых деградации липазой in vitro, также было отмечено уменьшение массы полимера. Пленки из П(ЗГБ-со-75 мол. \% 4ГБ) продемонстрировали значительное сокращение массы по сравнению с пленками из П(ЗГБсо-25 мол. \% 4ГБ). Деградированная полимерная пленка из П(ЗГБ) имела фибриллярную структуру, в то время как структура поверхности П(ЗГБ-со-4ГБ) стала более пористой. Данные полимеры успешно деградировали в окружающей среде, причем для П(ЗГБ-со-4ГБ) отмечалась более быстрая деградачия.

Ключевые слова: полигидроксиалканоаты, биополимеры, электростатическое формование, in vitro, деградаиия. 


\section{Introduction}

Polyhydroxyalkanoates (PHAs) act as intracellular storage compounds which provide energy and carbon sources to enhance survival of various environmental bacteria and archaea under environmental stress. In vivo, they are amorphous polymers which are synthesized in the presence of excess carbon with limiting concentration of at least one growth essential nutrient such as nitrogen, phosphorus, sulfur or oxygen. PHAs are accumulated intracellularly in the form of granules. In laboratory settings, different carbon sources can be fed to wild type or recombinant strain microorganisms to produce different types of PHA. PHA can be degraded by microorganisms such as bacteria and fungi in various environment such as soil, aquatic (sea water and lake water), landfills and activated sludge. Bacteria degrade PHA in the environment by secreting several enzymes, such as PHA depolymerase, lipase and esterase. In general, PHA accumulating bacteria have intracellular depolymerase whereas some non-PHA accumulating bacteria can produce extracellular depolymerase to degrade PHA derived from dead or lysed cells that accumulate PHA (Jendrossek \& Handrick, 2002). The microorganisms excrete extracellular PHA depolymerase to degrade environmental PHA and utilize the decomposed compounds as nutrient. Due to this biodegradable property, PHAs are attractive as substitute for some non-degradable petroleum based plastics.

Poly(3-hydroxybutyrate) $\quad[\mathrm{P}(3 \mathrm{HB})] \quad$ was discovered by Maurice Lemoigne in the 1920s (Lemoigne, 1926). P(3HB) is stiff, crystalline and brittle. This polymer consists of only one type of monomer, 3-hydroxybutyrate (3HB). P(3HB) can undergo three different kinds of degradation which mainly are enzymatic degradation, hydrolytic degradation and thermal degradation (Zhao \& Cheng, 2006). Degradation of P(3HB) homopolymer by PHA depolymerase is a kind of enzymatic degradation which can be intracellular or extracellular (Mergaert et al., 2000).

The incorporation of monomer 4-hydroxybutyrate (4HB) into $\mathrm{P}(3 \mathrm{HB})$ could decrease the crystallinity and melting point of the homopolymer. Thus, it improves the brittleness and crystallinity of $\mathrm{P}(3 \mathrm{HB})$. $4 \mathrm{HB}$ can be found in the brain, heart, liver, lung, kidney and muscle of mammalian body and degradable by lipases in vivo by surface erosion process (Nelson et al., 1981). P(3HB-co-4HB) copolymer can be degrade by lipase produced from mammalian body and is more suitable in tissue engineering (Griffith, 2002).

Electrospinning technique can be used to fabricate polymer fibers in the average diameter range of $100 \mathrm{~nm}$ to $5 \mu \mathrm{m}$. These fabricated mats are excellent scaffold that mimic the characteristics of extracellular matrix as they provide large surface area to volume ratios, flexibility in surface functionalities and high porosity (Ren et al., 2008). Polymer fibers are produced when the electrical forces at the surface of polymer solution in the spinneret overcome the surface tension and cause an electrically charged jet to be ejected on the surface of the electrically conductive collector (Frenot \& Chronakis, 2003).

Electrospinning technique had been employed in this study in which the different processing parameters and conditions were used to produce PHA films. The electrospun films of $\mathrm{P}(3 \mathrm{HB}), \mathrm{P}(3 \mathrm{HB}-c o-25 \mathrm{~mol} \% 4 \mathrm{HB})$ and $\mathrm{P}(3 \mathrm{HB}-$ co-75 mol \% 4HB) were characterized based on their surface morphology via Scanning Electron Microscopy (SEM) and degradation rate of these films were investigated under laboratory conditions and in the environment.

\section{Materials and methods}

\section{Materials}

Poly(3-hydroxybutyrate) [P(3HB)], poly(3hydroxybutyrate-co-25 mol\%4-hydroxybutyrate) 
$[\mathrm{P}(3 \mathrm{HB}-\mathrm{co}-25 \mathrm{~mol} \% \mathrm{4HB})]$ and poly(3hydroxybutyrate-co-75 mol \% 4-hydroxybutyrate) [P(3HB-co-75 mol \% 4HB)] were used in this study. Chloroform was purchased from Fischer Scientific, Malaysia. PHA depolymerase purified from Ralstonia pickettii T1 (Kasuya et al., 1996) was used and porcine lipase was purchased from Sigma, Malaysia.

\section{Preparation of polymer solution}

and phosphate buffer solution

$\mathrm{P}(3 \mathrm{HB}),[\mathrm{P}(3 \mathrm{HB}-\mathrm{co}-25 \mathrm{~mol} \mathrm{\%} 4 \mathrm{HB}]$ and [P(3HB-co-75 mol \% 4HB] were dissolved in chloroform at room temperature and were stirred for two days before filtering with Sartorius PTFE membrane filter $(0.2 \mu \mathrm{m}$ pore size). Precursor solution of $\mathrm{P}(3 \mathrm{HB})$ was first prepared at concentration of $1 \%, 2 \%, 3 \%$ and $4 \%$ without prior heating before electrospinning to investigate the optimum concentration. $\mathrm{P}(3 \mathrm{HB})$ polymer solution $(4 \%)$ and $\mathrm{P}(3 \mathrm{HB}-\mathrm{co}-4 \mathrm{HB})$ polymer solution $(1 \%)$ were heated for 5,10 , 15 and $20 \mathrm{~min}$ at $60{ }^{\circ} \mathrm{C}$ and for 15 and $20 \mathrm{~min}$ at $50{ }^{\circ} \mathrm{C}$ respectively before fabrication by electrospinning. Disodium hydrogen phosphate $\left(\mathrm{Na}_{2} \mathrm{HPO}_{4}\right)$ was added into $100 \mathrm{~mL}$ of distilled water to achieve the target molarity of $0.1 \mathrm{M}$. The $\mathrm{pH}$ of $0.1 \mathrm{M} \mathrm{Na}_{2} \mathrm{HPO}_{4}$ was adjusted to 7.4 using $0.1 \mathrm{M} \mathrm{HCl}$ solution.

\section{Electrospinning}

Electrospinning was performed using

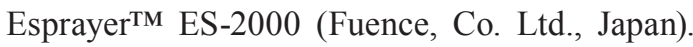
The polymer solution was loaded into a $1 \mathrm{~mL}$ stainless steel glass syringe with an inner needle diameter of $0.5 \mathrm{~mm}$. The syringe was set vertically at a distance of $20 \mathrm{~cm}$ from the collecting plate. $\mathrm{P}(3 \mathrm{HB})$ polymer solution of different concentrations were fabricated at 15 $\mathrm{kV}$ and extrusion rate of $40 \mu \mathrm{L} / \mathrm{min}$. Different voltages and solution extrusion rates were applied for other sample sets. The electrospun fibers were collected on the fiber collection area at different time intervals of 5, 10, 15 and $20 \mathrm{~min}$.

In vitro degradation of electrospun films

by PHA depolymerase and lipase

From the stock solution of $1.3 \mathrm{mg} / \mathrm{mL}$, $6 \mu \mathrm{L}$ of PHA depolymerase was added to 2 $\mathrm{mL}$ of phosphate buffer for the preparation of depolymerase enzyme solution. An amount of $0.167 \mathrm{~g}$ of porcine lipase enzyme powder $(30 \mathrm{U} /$ $\mathrm{mg}$ ) was dissolved in $100 \mathrm{~mL}$ of distilled water for preparation of $50 \mathrm{U} / \mathrm{mL}$ of stock solution. Approximately $2 \mathrm{~mL}$ of this solution was used for degradation of the electrospun film samples. Each film was cut $(1 \mathrm{~cm} \times 1 \mathrm{~cm})$, weighed and incubated in depolymerase enzyme solution for $\mathrm{P}(3 \mathrm{HB})$ samples while $\mathrm{P}(3 \mathrm{HB}-\mathrm{co}-25 \mathrm{~mol} \%$ 4HB) and $\mathrm{P}(3 \mathrm{HB}-\mathrm{co}-75 \mathrm{~mol} \% 4 \mathrm{HB})$ were incubated in lipase enzyme solution. The samples were placed in an incubator at $37{ }^{\circ} \mathrm{C}$ for $30,60,90$ and 120 $\mathrm{min}$. The films were removed from the enzyme solution and washed gently with distilled water before air-drying for one day. The weight of films was recorded and plotted in a line graph as a function of incubation time (min). Polymer weight loss was calculated as:

Initial weight (mg) -

Weight of film after incubation (mg)

The rate of degradation was calculated as follow:

[Initial weight of film -

Weight of film after incubation] (mg)

Incubation time (min)

\section{Degradation of films}

in aquatic environment

Electrospun polymer films were inserted into four twin pouches of a nylon mesh jacket with each 
pouch measuring $2.5 \mathrm{~cm} \times 2.5 \mathrm{~cm}$ and with pore diameter of $2.54 \mathrm{~mm}$. The mesh jacket was tied to holes drilled on a polyvinylchloride (PVC) core measuring $60 \mathrm{~cm}$ in length and $15 \mathrm{~cm}$ in diameter and dipped into a freshwater lake in Universiti Sains Malaysia. Small holes were drilled into the PVC core to facilitate water exchange during the one week of study. The samples were retrieved after one week, washed gently and allow to airdry before examination under Scanning Electron Microscopy (SEM).

\section{Scanning electron microscopy (SEM)}

The morphologies of the electrospun films were examined by SEM (Leo Supra 50VP Field emission, magnification of 1,000 to 50,000 times) before and after the films were subjected to various degradation. The samples were mounted on an aluminium stub and sputter-coated with a layer of gold. Three voltages of $5 \mathrm{kV}, 10 \mathrm{kV}$ and $15 \mathrm{kV}$ were applied to obtain the images of desired films.

\section{Results}

\section{Fabrication}

$\mathrm{P}(3 \mathrm{HB}), \mathrm{P}(3 \mathrm{HB}-c o-25 \mathrm{~mol} \% 4 \mathrm{HB})$ and $\mathrm{P}(3 \mathrm{HB}-c o-75 \mathrm{~mol} \%$ 4HB) polymers were fabricated using electrospinning method and the surface morphologies were observed under SEM.
Voltage of $30 \mathrm{kV}$ with extrusion rate of $60 \mu \mathrm{L} /$ min was applied to $4 \% \mathrm{P}(3 \mathrm{HB})$ and it showed interconnected short fibers that may be further investigated to obtain fibrous structures (Fig. 1a). The solution was also heated at $60^{\circ} \mathrm{C}$ for $5,10,15$ and $20 \mathrm{~min}$ and electrospun with the same voltage and extrusion rate. $\mathrm{P}(3 \mathrm{HB})$ polymer solution heated for $15 \mathrm{~min}$ before fabrication produced fibers interconnected with bead structures whereas the morphologies of other heating time showed porous homogenous flat structures (Fig. 2). $\mathrm{P}(3 \mathrm{HB})$ with different concentrations were also fabricated with $15 \mathrm{kV}$ and $40 \mu \mathrm{L} / \mathrm{min}$. The surface morphologies were similar but with increasing complicacy amongst the interconnected fibers and beads as the concentration increased from $1 \%$ to $3 \%$. However, $4 \% \mathrm{P}(3 \mathrm{HB})$ appeared to be homogenous beaded structures which were clumped together (Fig. 1b).

$\mathrm{P}(3 \mathrm{HB}-\mathrm{co}-25 \mathrm{~mol} \% 4 \mathrm{HB})$ and $\mathrm{P}(3 \mathrm{HB}-\mathrm{co}-$ $75 \mathrm{~mol} \% 4 \mathrm{HB})$ fabricated after heating at $50{ }^{\circ} \mathrm{C}$ did not show network structure. Instead, P(3HBco-25 mol \% 4HB) fabricated surface appeared to be rough and uneven with hollow depression after heating for 15 and $20 \mathrm{~min}$ (Fig. 3a \& b). P(3HBco-75 mol \% 4HB) surface showed smooth and bead structures when heating was increased to 20 $\min$ (Fig. 3c \& d). Both surface morphology of $1 \% \mathrm{P}(3 \mathrm{HB}-\mathrm{co}-25 \mathrm{~mol} \% 4 \mathrm{HB})$ and $1 \% \mathrm{P}(3 \mathrm{HB}-$
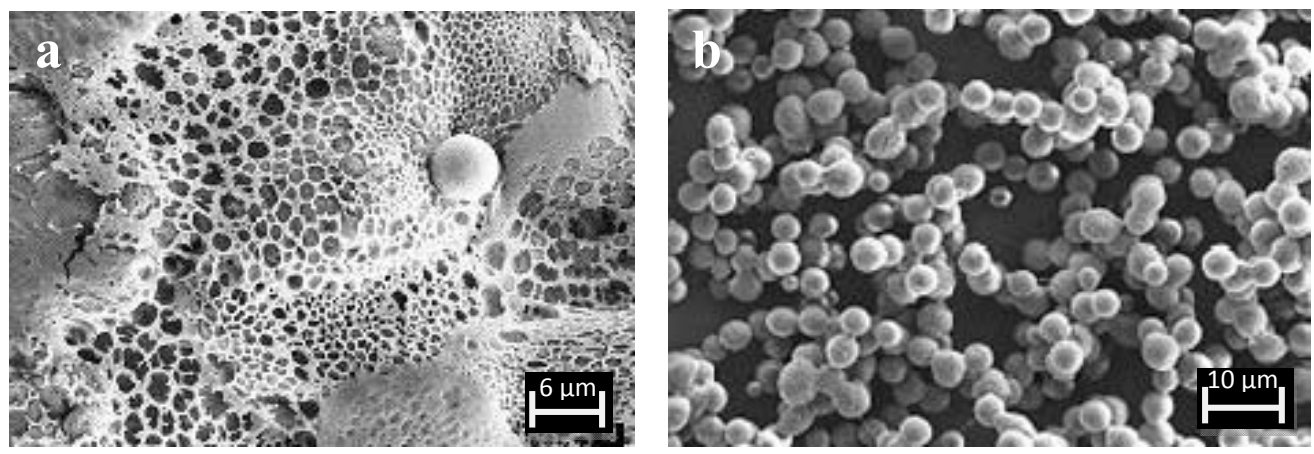

Fig. 1: SEM image of $4 \% \mathrm{P}(3 \mathrm{HB}$ ) electrospun at (a) $30 \mathrm{kV}$ with extrusion rate $60 \mu \mathrm{L} / \mathrm{min}$ and (b) $15 \mathrm{kV}$ with 40 $\mu \mathrm{L} / \mathrm{min}$ of extrusion rate 

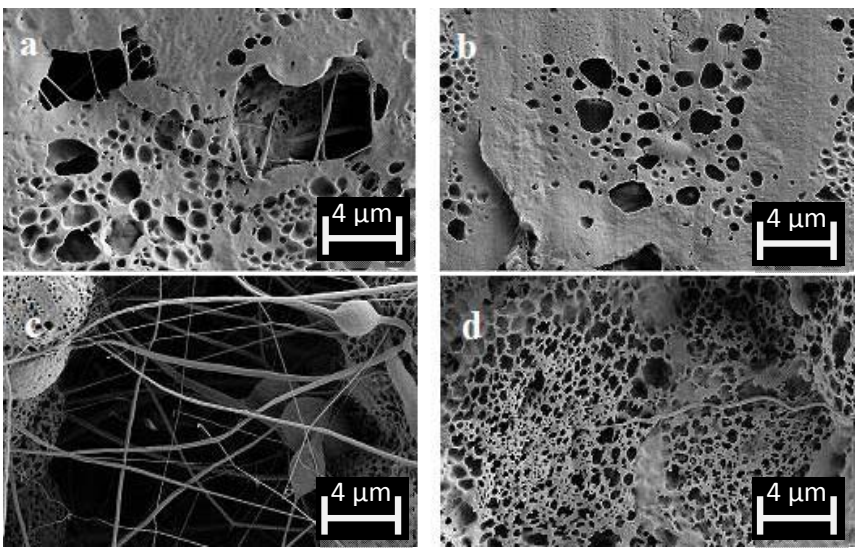

Fig. 2: SEM image of $4 \% \mathrm{P}(3 \mathrm{HB})$ electrospun at $30 \mathrm{kV}, 60 \mu \mathrm{L} / \mathrm{min}$ with prior heating of polymer solution at 60 ${ }^{\circ} \mathrm{C}$ before fabrication for (a) $5 \mathrm{~min}$; (b) $10 \mathrm{~min}$; (c) $15 \mathrm{~min}$; (d) $20 \mathrm{~min}$
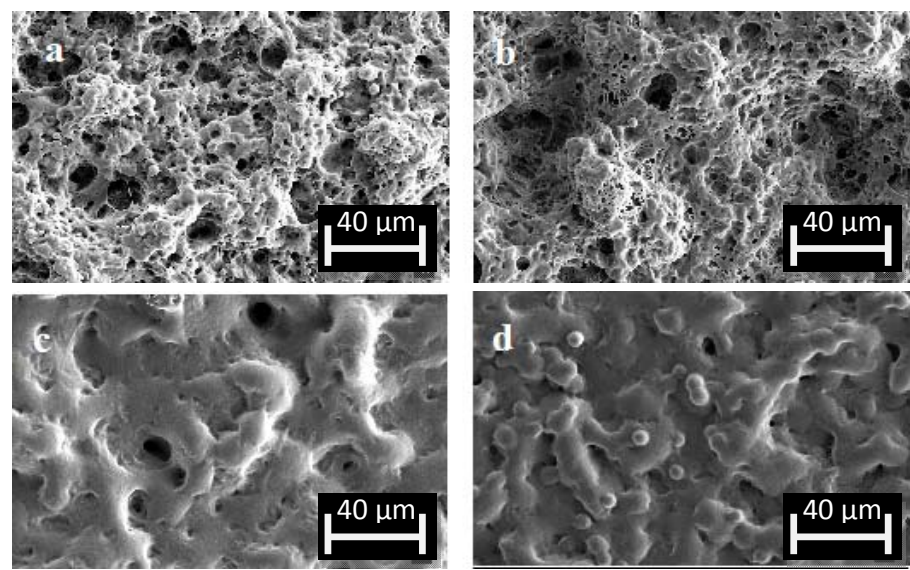

Fig. 3: SEM image (x1000) of $1 \% \mathrm{P}(3 \mathrm{HB}-\mathrm{co}-25 \mathrm{~mol} \%$ 4HB) fabricated by electrospinning at $30 \mathrm{kV}, 60 \mu \mathrm{L} / \mathrm{min}$ with prior heating of polymer solution at $50{ }^{\circ} \mathrm{C}$ for (a) $15 \mathrm{~min}$; (b) $20 \mathrm{~min} .1 \% \mathrm{P}(3 \mathrm{HB}-\mathrm{co}-75 \mathrm{~mol} \% 4 \mathrm{HB})$ heated at $50{ }^{\circ} \mathrm{C}$ for (c) $15 \mathrm{~min}$; (d) $20 \mathrm{~min}$

co-75 mol \% 4HB) were dissimilar. Surface of $\mathrm{P}(3 \mathrm{HB}-\mathrm{co}-75 \mathrm{~mol} \% 4 \mathrm{HB})$ was more rounded and smooth compared to $\mathrm{P}(3 \mathrm{HB}-\mathrm{co}-25 \mathrm{~mol} \% 4 \mathrm{HB})$ which appeared to be rough and uneven with tiny hollow depressions spread all over the surface (Fig. 4).

\section{Environmental degradation}

Exposure of $\mathrm{P}(3 \mathrm{HB}), \mathrm{P}(3 \mathrm{HB}-\mathrm{co}-25 \mathrm{~mol} \%$ $4 \mathrm{HB})$ and $\mathrm{P}(3 \mathrm{HB}-\mathrm{co}-75 \mathrm{~mol} \%$ 4HB) films electrospun for $15 \mathrm{~min}$ were subjected to environmental degradation for a period of one week. $\mathrm{P}(3 \mathrm{HB})$ with solution concentration $3 \%$ and $4 \%$ showed difference in morphology after a week of immersion in the freshwater lake. Morphology of $3 \% \mathrm{P}(3 \mathrm{HB})$ changed from being intertwined mesh fibers and beads (Fig. 5a) to scattered remains of polymer and diatoms (Fig. $5 \mathrm{~b}$ ). On the other hand, the homogeneous hollow beads of $4 \%$ $\mathrm{P}(3 \mathrm{HB})$ (Fig. 5c) turned into a big clump of rough polymer with diatoms intertwined after a week of aquatic environment exposure (Fig. 5d). The degradation of $3 \% \mathrm{P}(3 \mathrm{HB})$ was relatively better than $4 \% \mathrm{P}(3 \mathrm{HB})$. The $1 \% \mathrm{P}(3 \mathrm{HB}-c o-25 \mathrm{~mol} \%$ 

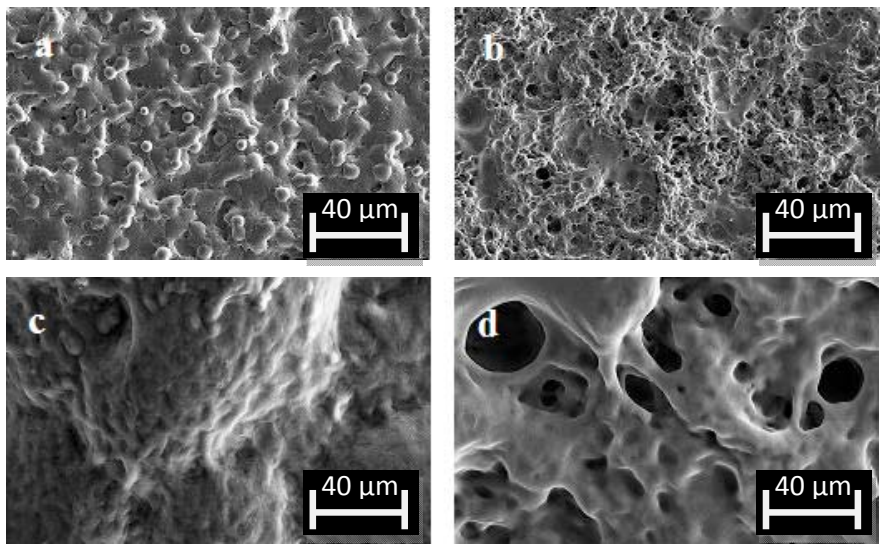

Fig. 4: SEM image of $\mathrm{P}(3 \mathrm{HB}-c o-4 \mathrm{HB})$ fabricated by electrospinning at $30 \mathrm{kV}$ and extrusion rate of $60 \mu \mathrm{L} / \mathrm{min}$. (a) $1 \% \mathrm{P}(3 \mathrm{HB}-c o-75 \mathrm{~mol} \%$ 4HB) (x 500); (b) $1 \% \mathrm{P}(3 \mathrm{HB}-c o-25 \mathrm{~mol} \% 4 \mathrm{HB}$ ) (x 500); (c) $1 \% \mathrm{P}(3 \mathrm{HB}-\mathrm{co}-75 \mathrm{~mol} \%$ 4HB) (x5,000); (d) $1 \% \mathrm{P}(3 \mathrm{HB}-\mathrm{co}-25 \mathrm{~mol} \%$ 4HB) $(\mathrm{x} 5,000)$
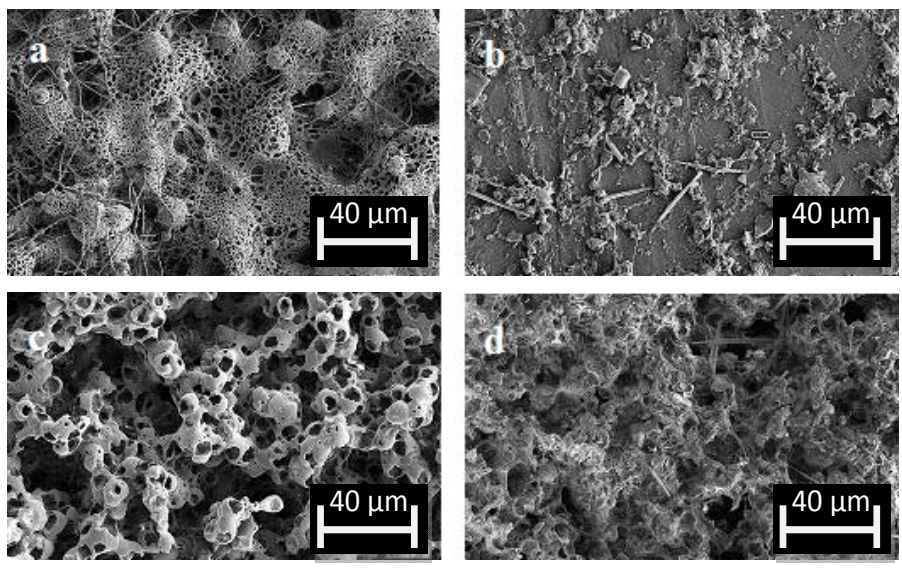

Fig. 5: SEM image of $\mathrm{P}(3 \mathrm{HB})$ subjected to environmental degradation for a period of 1 week. (a) $3 \% \mathrm{P}(3 \mathrm{HB})$ before degradation; (b) $3 \% \mathrm{P}(3 \mathrm{HB})$ after degradation; (c) $4 \% \mathrm{P}(3 \mathrm{HB})$ before degradation; (d) $4 \% \mathrm{P}(3 \mathrm{HB})$ after degradation

$4 \mathrm{HB})$ and $\mathrm{P}(3 \mathrm{HB}-\mathrm{co}-75 \mathrm{~mol} \%$ 4HB) electrospun films also showed signs of degradation after one week exposure in freshwater lake with $\mathrm{P}(3 \mathrm{HB}-$ co-75 mol \% 4HB) showing better degradation as the film appeared relatively clear (Fig. 6).

\section{In vitro degradation}

of electrospun $\mathrm{P}(3 \mathrm{HB})$ films

in depolymerase enzyme solution

Effects of in vitro biodegradation by PHA depolymerase on different film thicknesses and concentrations of electrospun $\mathrm{P}(3 \mathrm{HB})$ films were assessed through percentage weight loss. The $4 \%$ $\mathrm{P}(3 \mathrm{HB})$ electrospun films of different thickness (determined through duration of electrospinning of 5, 10, 15 and $20 \mathrm{~min}$ ) expressed significant weight loss throughout the $2 \mathrm{~h}$ incubation period. Films spun for 5 and 10 min showed a gradual weight loss as compared to electrospun films of 15 and 20 min which exhibited a rather sharp decrease in their weight (Fig. 7). Electrospun films fabricated for $15 \mathrm{~min}$ showed the highest degradation 

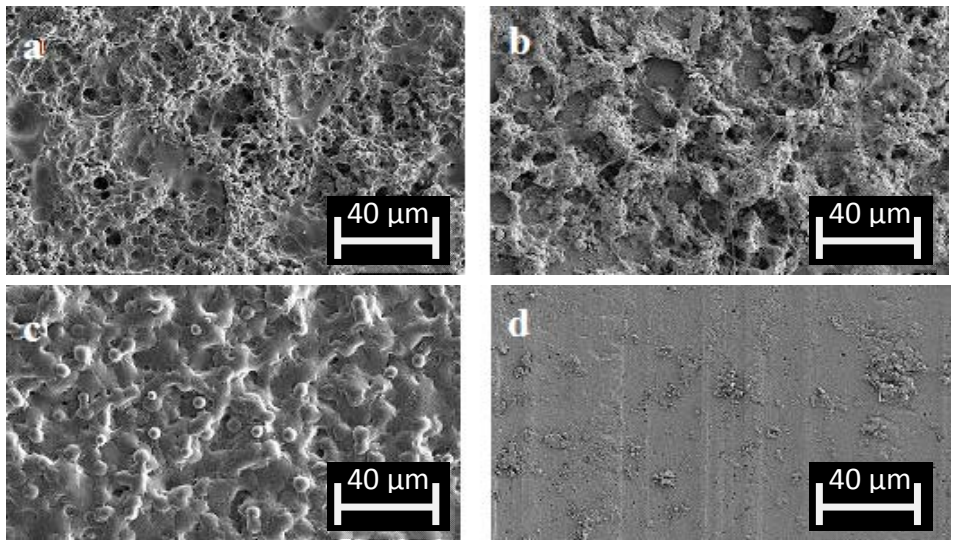

Fig. 6: SEM image of $\mathrm{P}(3 \mathrm{HB}-\mathrm{co}-4 \mathrm{HB})$ subjected to environmental degradation for a period of 1 week. (a) $\mathrm{P}(3 \mathrm{HB}-$ co-25 mol \% 4HB) before degradation; (b) $\mathrm{P}(3 \mathrm{HB}-c o-25 \mathrm{~mol} \% 4 \mathrm{HB})$ after degradation; (c) $\mathrm{P}(3 \mathrm{HB}-c o-75 \mathrm{~mol} \%$ $4 \mathrm{HB})$ before degradation; (d) $\mathrm{P}(3 \mathrm{HB}-\mathrm{co}-75 \mathrm{~mol} \% 4 \mathrm{HB})$ after degradation

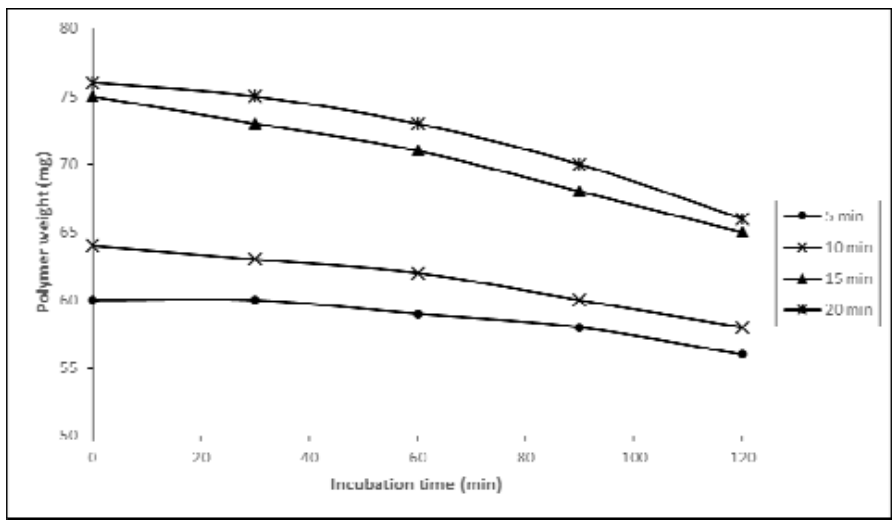

Fig. 7: Weight loss of electrospun $\mathrm{P}(3 \mathrm{HB})$ films fabricated at different time durations $(5,10,15$ and 20 min) after incubation in depolymerase enzyme at $37^{\circ} \mathrm{C}$

rate (Fig. 8). The degradation rate remained almost constant as the electrospinning time was increased to $20 \mathrm{~min}$. Thus, $15 \mathrm{~min}$ fabrication time was fixed in subsequent experiments. $\mathrm{P}(3 \mathrm{HB})$ polymers with concentrations of $1 \%, 2 \%, 3 \%$ and $4 \%$ which were electrospun for 15 min were all degraded by PHA depolymerase. Electrospun $3 \%, 4 \% \mathrm{P}(3 \mathrm{HB})$ films were degraded in a rather parallel fashion showing a gradual but steady decrease in polymer weight. The $2 \% \mathrm{P}(3 \mathrm{HB})$ film was degraded faster compared to the $1 \% \mathrm{P}(3 \mathrm{HB})$ which exhibited slow decrease in polymer weight
(Fig. 9). There was a sharp increase in degradation rate when electrospun $\mathrm{P}(3 \mathrm{HB})$ film concentration shifted from $1 \%(0.03 \mathrm{mg} / \mathrm{min})$ to $2 \%(0.14$ $\mathrm{mg} / \mathrm{min})$. The $2 \% \mathrm{P}(3 \mathrm{HB})$ films showed the highest degradation rate amongst the other films electrospun at different concentrations. After the peak at $2 \%$, further increase in polymer solution concentration resulted in a decrease of degradation rate whereby the rate was approximately $0.1 \mathrm{mg} /$ min. Degradation rate of $3 \%$ and $4 \% \mathrm{P}(3 \mathrm{HB})$ electrospun films by PHA depolymerase at $37^{\circ} \mathrm{C}$ remained constant throughout the experiment. 


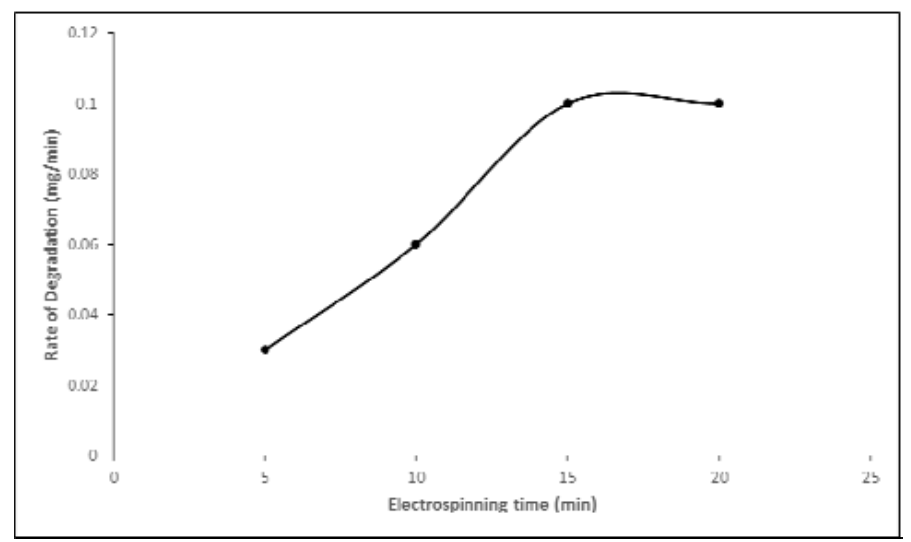

Fig. 8: Degradation rate of electrospun $\mathrm{P}(3 \mathrm{HB})$ films fabricated at different time durations after incubation in PHA depolymerase at $37^{\circ} \mathrm{C}$

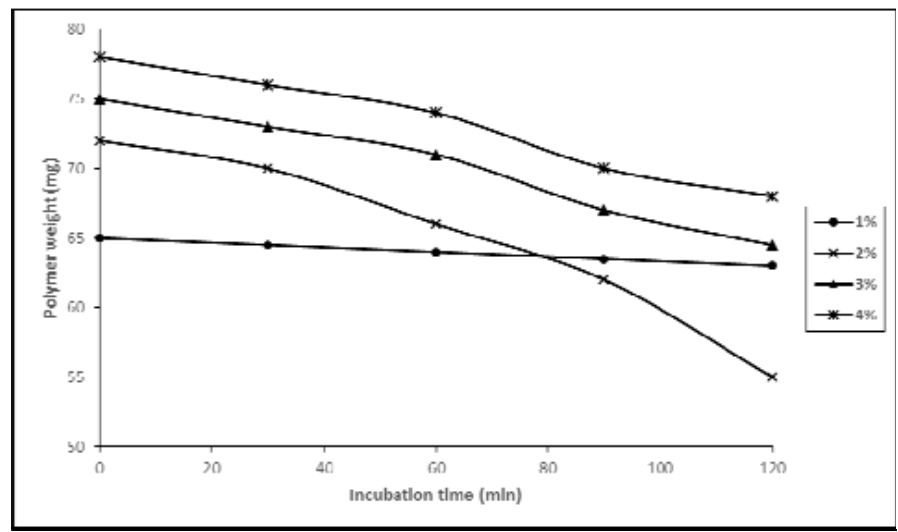

Fig. 9: Weight loss of $\mathrm{P}(3 \mathrm{HB})$ films electrospun for 15 min using different $\mathrm{P}(3 \mathrm{HB})$ concentrations after incubation in PHA depolymerase at $37^{\circ} \mathrm{C}$

\section{In vitro degradation}

of electrospun $\mathrm{P}(3 \mathrm{HB}-\mathrm{co}-4 \mathrm{HB})$ films

in lipase enzyme solution

$\mathrm{P}(3 \mathrm{HB}-\mathrm{co}-25 \mathrm{~mol} \%$ 4HB) was electrospun for 5, 10, 15 and 20 min to test the effect of layer thickness on in vitro biodegradation using lipase enzyme solution. The weight loss of P(3HB-co$25 \mathrm{~mol} \% 4 \mathrm{HB}$ ) electrospun films fabricated at different time durations after incubation in lipase enzyme (Fig. 10) showed that 5 min electrospun film started to degrade after 60 min whereas both 15 and 20 min electrospun film started at $30 \mathrm{~min}$ but with a difference in the decline pattern. The
15 min electrospun film exhibited a big decline in polymer weight after $60 \mathrm{~min}$ of incubation and gradual decline after 90 and 120 min of incubation. The 20 min electrospun film was degraded after 30 min but the weight remained constant for a period of one hour before another plunge in the graph indicating weight loss at $120 \mathrm{~min}$. The weight decline after $30 \mathrm{~min}$ of incubation for the polymer electrospun for 10 min was negligible as the weight loss was not significant and did not show any further decrease in weight for another 90 min thereafter (Fig. 10). P(3HB-co-4HB) films electrospun for different period of time showed 


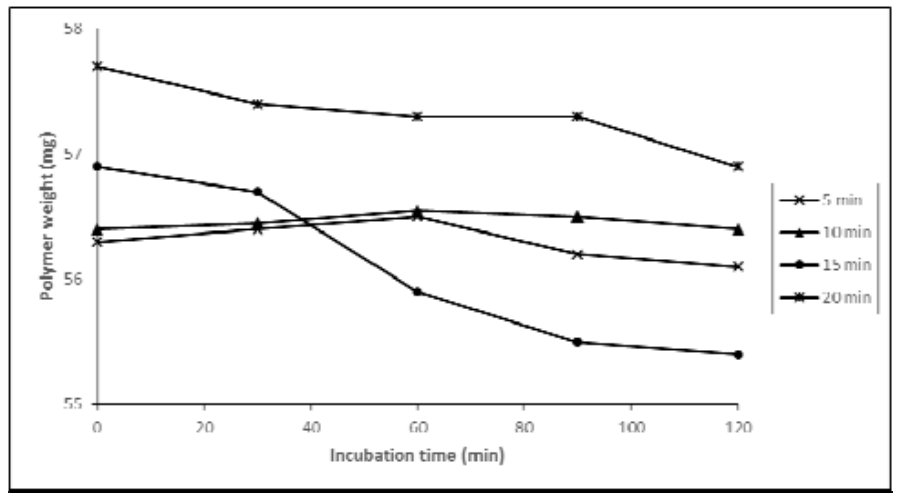

Fig. 10: Weight loss of $\mathrm{P}(3 \mathrm{HB}-\mathrm{co}-25 \mathrm{~mol} \% 4 \mathrm{HB})$ electrospun films fabricated at different time durations after incubation in lipase enzyme at $37^{\circ} \mathrm{C}$

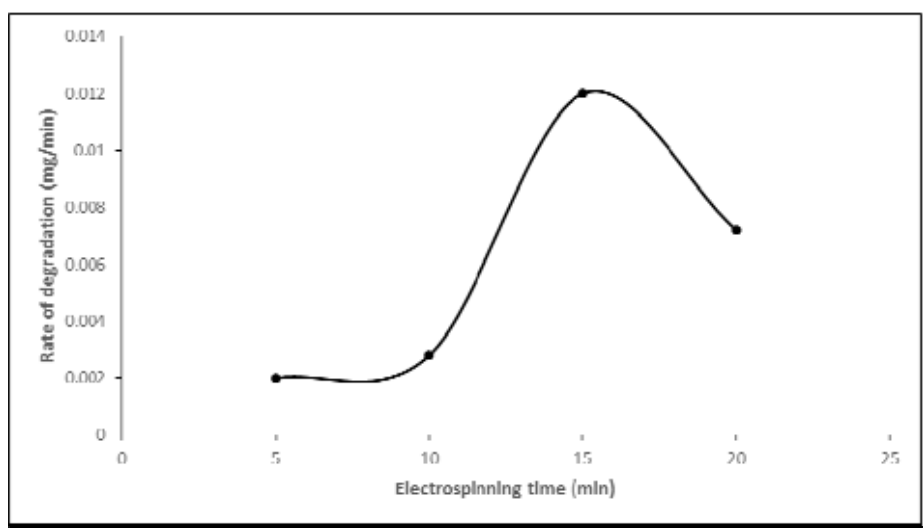

Fig. 11: Degradation rate of $\mathrm{P}(3 \mathrm{HB}-\mathrm{co}-25 \mathrm{~mol} \% 4 \mathrm{HB})$ electrospun film fabricated at different time durations after incubation in lipase enzyme at $37^{\circ} \mathrm{C}$

similar trend as $\mathrm{P}(3 \mathrm{HB})$. Films electrospun for 15 min showed the highest value of degradation rate $(0.013 \mathrm{mg} / \mathrm{min})$ and it dropped to $0.007 \mathrm{mg} / \mathrm{min}$ for films fabricated for $20 \mathrm{~min}$ (Fig. 11).

The semitransparent $\mathrm{P}(3 \mathrm{HB}-\mathrm{co}-75 \mathrm{~mol} \%$ 4HB) fabricated at different time durations showed weight loss after incubation in lipase enzyme at $37{ }^{\circ} \mathrm{C}$ (Fig. 12). Graphs of electrospun films fabricated at 5, 10 and $20 \mathrm{~min}$ showed a rather similar pattern in polymer weight decline throughout the $2 \mathrm{~h}$ of incubation. Similarly, the 15 min electrospun films also exhibited a decrease in its polymer weight but unlike the other films, this film showed a sharp decline after $30 \mathrm{~min}$ of incubation and polymer weight continued to decrease drastically until it reached its lowest point at $120 \mathrm{~min}$. The degradation rates of $\mathrm{P}(3 \mathrm{HB}-$ co-75 $\mathrm{mol} \% 4 \mathrm{HB}$ ) at 5, 10, 15 and $20 \mathrm{~min}$ (Fig. 13) were similar to the degradation rate of $\mathrm{P}(3 \mathrm{HB}-\mathrm{co}$ $25 \mathrm{~mol} \%$ 4HB) (Fig. 11) with 15 min electrospun film exhibiting the highest degradation rate at $0.035 \mathrm{mg} / \mathrm{min}$ followed by a decrease at $20 \mathrm{~min}$ electrospun films $(0.025 \mathrm{mg} / \mathrm{min})$.

\section{Discussion}

\section{Fabrication}

Electrospun fibers have high surface areato-volume ratio, porous and enhanced specific 


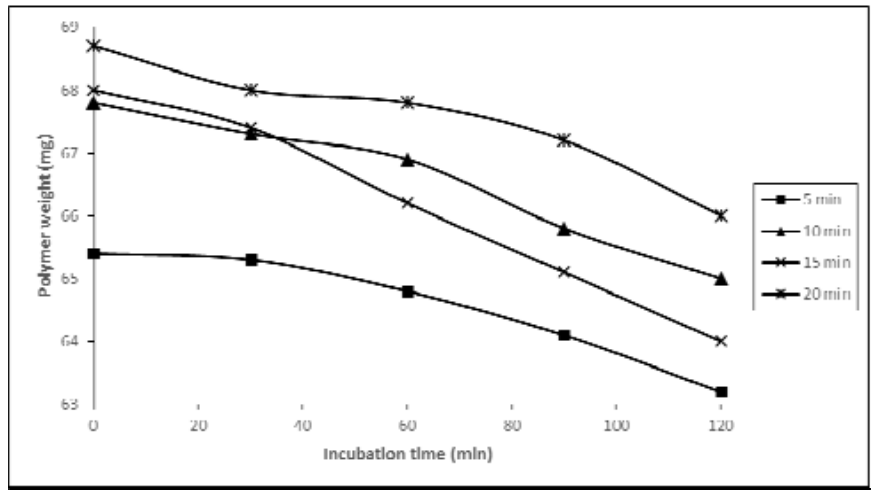

Fig. 12: Weight loss of $\mathrm{P}(3 \mathrm{HB}-\mathrm{co}-75 \mathrm{~mol} \% 4 \mathrm{HB})$ electrospun films fabricated at different time durations after incubation in lipase enzyme at $37^{\circ} \mathrm{C}$

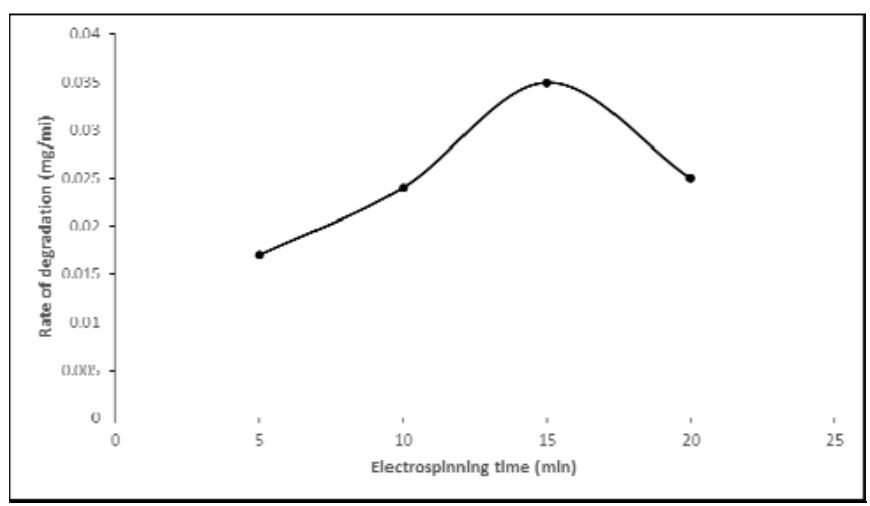

Fig. 13: Degradation rate of $\mathrm{P}(3 \mathrm{HB}-\mathrm{co}-75 \mathrm{~mol} \% 4 \mathrm{HB})$ electrospun films fabricated at different time durations after incubation in lipase enzyme at $37^{\circ} \mathrm{C}$

mechanical performance for various applications such as filtration media, tissue engineering, electronic applications, nanosensors and many more (Cheng et al., 2008). Viscosity of polymer solution is one of the key parameter that affects fiber morphology. Solution viscosity also influences fiber diameter, initiating droplet shape and the jet stream. Viscous polymer solution is important in the fiber forming process because the initial jet does not break up in droplets but instead the solvent (chloroform) will evaporate as the jet proceeds to the target leaving behind the polymer fiber. Uniform fibers will form as the bead shape changes from spherical to thread- like with the increase in viscosity. The presence of repulsive Coulomb interactions in fluid jet charged elements could lead to development of beaded structure along with the fibers (Agarwal et al., 2013). Polymer solution of $4 \% \mathrm{P}(3 \mathrm{HB})$ was heated up for 5, 10, 15 and 20 min respectively before fabrication to increase polymer viscosity and homogeneous mixing which could promote fiber formation (Fig. 2). The increase in polymer concentration within the optimal concentration range could promote formation of fiber with larger diameter (Wang et al., 2013). The $4 \%$ P(3HB) heated up to $15 \mathrm{~min}$ at $60{ }^{\circ} \mathrm{C}$ before fabrication produced more fibrous network but still the 
morphology of 'bead on a string' was inevitable. It was found that electrospinning from solutions heated for more than $15 \mathrm{~min}$ only produced porous interconnected mesh as homogeneous fiber formation was prohibited by high viscosity. The highly viscous polymer solution proved difficult to force through the syringe and thus making the extrusion rate from the tip unstable and render formation of fibers difficult (Fig. 2d). $\mathrm{P}(3 \mathrm{HB}-\mathrm{co}$ $25 \mathrm{~mol} \% 4 \mathrm{HB}$ ) and $\mathrm{P}(3 \mathrm{HB}-c o-75 \mathrm{~mol} \mathrm{\%} 4 \mathrm{HB})$ electrospun films did not produce fibrous network although the polymer solutions were heated for 15 and $20 \mathrm{~min}$ before fabrication. This may be due to low viscosity of $\mathrm{P}(3 \mathrm{HB}-\mathrm{co}-4 \mathrm{HB})$ that prohibited fiber formation. Beaded structures were more prone to form in polymer solutions fabricated at low viscosity because droplets will be formed at the nozzle of the syringe (Fig. 3).

Increase in polymer concentration has two major effects on the electrospinning process which are an increase in the evaporation rate and fiber pulling force. According to Deitzel et al. (2001), fiber diameter increases as the solution concentration increases. Polymer concentration is also correlated with the viscosity factor. Research has proven that at higher concentrations of polymer solution, fibers are prone to form. This is due to the entanglement of viscous polymer molecule that prevents the breakup of jet directed towards the collector (Cheng, 2008). However in this study, $3 \% \mathrm{P}(3 \mathrm{HB})$ solution showed more signs of possible fiber formation compared to $4 \%$ $\mathrm{P}(3 \mathrm{HB})$.

$\mathrm{P}(3 \mathrm{HB})$ is a stiff, crystalline and brittle polyester. Due to these limitations, incorporation of a second monomer, $4 \mathrm{HB}$ into $\mathrm{P}(3 \mathrm{HB})$ polymer backbone improves its physical characteristics. $\mathrm{P}(3 \mathrm{HB}-\mathrm{co}-4 \mathrm{HB})$ shows properties from being crystalline to elastic and is suitable for a wide range of applications. One of the significant application is to mimic the real microenvironment of extracellular matrix (ECM) (Li et al., 2008) by which electrospinning could obtain threedimensional continuous fibrous network morphology. Fibrous network changed into porous mats with well distributed beads in $\mathrm{P}(3 \mathrm{HB}-\mathrm{co}-75 \mathrm{~mol} \% 4 \mathrm{HB})$ as the ratio of $4 \mathrm{HB}$ increased (Fig. $4 \mathrm{a} \&$ b). Thus, it is suggested that the mixing ratio of $4 \mathrm{HB}$ into $\mathrm{P}(3 \mathrm{HB})$ polymer backbone to be maintained in an equilibrium of percentage of $4 \mathrm{HB}$ above $25 \%$ but below $75 \%$ to allow formation of a continuous fibrous network. Further study is needed to establish the optimal copolymer percentage which can produce the desired fibrous matrix. Matrices of $\mathrm{P}(3 \mathrm{HB}-\mathrm{co}-$ $75 \mathrm{~mol} \%$ 4HB) showed decreased porosities accompanied with blurred fibrous structures and beaded defects. Chloroform is the only organic solvent used in this study to dissolve polymers as it allows full extension of the polymer and evaporates completely after fiber formation without leaving any residue on the formed fibers. Therefore, the effect of solvent in producing fibers is not applicable here.

\section{In vitro degradation}

of electrospun $\mathrm{P}(3 \mathrm{HB})$ film

in depolymerase enzyme solution

PHA depolymerases are carboxyesterases that hydrolyse water insoluble PHA into watersoluble oligomers and monomers sequentially. The monomers are then metabolized into water and carbon dioxide or methane by other enzymes (Amara, 2008). The enzymatic degradation of the polymers by PHA depolymerase involves two distinct domains. The initial stage whereby the initial adsorption of PHA depolymerase molecules onto the surface of $\mathrm{P}(3 \mathrm{HB})$ through enzyme substrate-binding domain (C-terminal substrate binding domain) exhibited relatively slow rate of weight loss as shown in Figure 7. Adsorption is then subsequently followed by the hydrolysis of polymer backbone through the activity of enzyme catalytic domain (N-terminal 
catalytic domain). Second step is essential as it is the stage whereby the degradation of polymer by PHA depolymerase shows rapid weight loss. The rate of enzyme excision increases and continuous weight loss is derived from the fragmentation of sample and diffusion of oligomers from the bulk polymer samples (Sudesh et al., 2000; Wang et al., 2008). Depolymerase enzyme used in this study was extracted from Ralstonia pickettii. Previous studies have shown that PHA depolymerase isolated from this bacterial species attaches first to the amorphous region as it is easily accessible to enzyme compared to the crystalline structure. The degradation rate of the polymer depends on monomer composition and degree of crystallinity (Li et al., 2007). Films fabricated for 5, 10, 15 and 20 min showed slow degradation initially when incubated in the buffer solution containing PHA depolymerase but degradation became quicker as incubation time increased. The weight of polymer films increased significantly as the electrospinning time increased. The film electrospun for $15 \mathrm{~min}$ showed the highest degradation rate $(0.1 \mathrm{mg} / \mathrm{min})$ (Fig. 8) and this could be because the sprayed sample achieved the highest surface area on the limited $1 \mathrm{~cm}$ x $1 \mathrm{~cm}$ collecting area. This enabled more depolymerase enzymes to attach efficiently. The rate of degradation increased proportionally with the surface area as more binding domains for attachment of enzymes are available. Enzymatic degradation of PHA films was performed under incubation at $37^{\circ} \mathrm{C}$ and $\mathrm{pH}$ 7.4. The electrospun films with fabrication time of $20 \mathrm{~min}$ did not show significant increase in rate of degradation (Fig. 8). This indicated that the prolonged electrospinning time did not significantly increase surface area of the film.

Afterdetermining theoptimalelectrospinning time at $15 \mathrm{~min}$, the study was preceded by investigating the effect of $\mathrm{P}(3 \mathrm{HB})$ solution concentration on the rate of polymer degradation. There was no clear correlation between initial weight and the degradation rate of the polymer because all films were significantly degraded with $1 \% \mathrm{P}(3 \mathrm{HB})$ being the least degraded and $2 \%$ being the most degraded as shown in Figure 13. Slow degradation was observed initially and thereafter degradation became faster. The highest rate of degradation showed in $2 \% \mathrm{P}(3 \mathrm{HB})$ may be due to its higher surface area which favors the adsorption and hydrolysis process of the PHA depolymerase. The increase in concentration of the electrospun films to $3 \%$ and $4 \%$ did not increase the rate further as the surface of the polymer was probably totally saturated with enzyme. There is no extra surface area for the attachment of the enzymes. Another explanation would be that there is no more available enzyme to degrade the electrospun films. Control in this study showed no weight loss when immersed in phosphate buffer without enzyme thus indicating no significant polymer hydrolysis occurred during incubation in buffer solution.

\section{In vitro degradation}

of electrospun $P(3 H B-c o-4 H B)$ film

in lipase enzyme solution

The degradation mechanism of lipase enzyme on $\mathrm{P}(3 \mathrm{HB}-$ co-4HB) copolymer was similar to the degradation of depolymerase enzyme on $\mathrm{P}(3 \mathrm{HB})$ homopolymer in which the amorphous region of the copolymer was favorable for enzyme attachment and activity (Hsieh et al., 2006; Mitomo et al., 2001). SEM studies on both polymers showed that the porosity of polymer increased after degradation and indicated successful lipase degradation on polymer surface (Fig. 10). Earlier researches have shown that the monomer composition and degree of crystallinity of copolymer influences the rate of degradation by lipase enzyme (Hsieh et al., 2006). Therefore, an increase in the incorporation of $4 \mathrm{HB}$ monomers into $3 \mathrm{HB}$ backbone will increase the rate of degradation due to lower crystallinity. Lipase 
cleave the ester bonds of aliphatic polyesters at the monomer sequence of (4HB)-(4HB) but not (4HB)-(3HB). In $\mathrm{P}(3 \mathrm{HB}-c o-4 \mathrm{HB})$, the erosion rate by lipase was higher with higher content of $4 \mathrm{HB}$ in the copolymer (Tan, 2003). Another reason that supports the theory that the lipase enzyme may share a similar mechanism in substrate hydrolysis with PHA depolymerase is that lipase also have a common amino acid sequence around the active side, Gly- $\mathrm{X}_{1}$-Ser- $\mathrm{X}_{2}$-Gly, which is also observed in PHA depolymerase. The only difference is that the $\mathrm{X}_{1}$ residue in PHA depolymerase is substituted with histidine in lipase (Tokiwa \& Calabia, 2004). In this study, lipase from SigmaAldrich, extracted from porcine pancreas was used in the form of lyophilized powder with an activity of $\geq 20,000$ units/mg protein.

Comparisons between the in-vitro degradation of $\mathrm{P}(3 \mathrm{HB}-\mathrm{co}-25 \mathrm{~mol} \% 4 \mathrm{HB})$ and $\mathrm{P}(3 \mathrm{HB}-\mathrm{co}-75 \mathrm{~mol} \% 4 \mathrm{HB})$ electrospun for 5, 10, 15 and 20 min respectively was done to elucidate optimal electrospinning time for maximum degradation and also to investigate the effects of 4HB ratio on the degradation rate (Fig. $10 \& 13$ ). The two polymers exhibited increase in initial polymer weight as the electrospinning time increased. The highest rate of degradation was observed in 15 min electrospinning time of P(3HBco-25 mol \% 4HB) and $\mathrm{P}(3 \mathrm{HB}-c o-75 \mathrm{~mol} \%$ $4 \mathrm{HB})$. The increase of surface area in which the collection area was $1 \mathrm{~cm} \mathrm{x} 1 \mathrm{~cm}$ was proportional to the increase of degradation rate as there were more surface for enzyme attachment. The increase in electrospinning time to $20 \mathrm{~min}$ did not give any significant increase in degradation rate. This prolonged fabrication time did not exactly increased the surface area for enzyme attachment but only increase the polymer weight in general. Spherulitic textures emerging from the bulk polymer after degradation with lipase were likely caused by the removal of amorphous component during degradation. The amorphous region of polymer samples is degraded preferentially (Wang et al., 2008). However, there are some drawbacks in this study as agitation was not introduced for fear of mechanical erosion of $\mathrm{P}(3 \mathrm{HB}-\mathrm{co}-4 \mathrm{HB})$ films. Therefore, the homogeneity of enzyme distribution was probably compromised because the lipase solution was only resuspended using a pipette at the start point of the experiment.

Generally, $\mathrm{P}(3 \mathrm{HB}-$ co-75 mol \% $4 \mathrm{HB})$ degradation was three times better than $\mathrm{P}(3 \mathrm{HB}-$ co-25 mol \% 4HB). This indicated that the rate of degradation due to incorporation of higher content of $4 \mathrm{HB}$ decreased the crystallinity. In P(3HBco-75 mol \% 4HB), there was higher occurrence of (4HB)-(4HB) monomer chains in the $\mathrm{P}(3 \mathrm{HB})$ backbone. As a result, the chances of lipase enzymes degrading the $\mathrm{P}(3 \mathrm{HB}-\mathrm{co}-75 \mathrm{~mol} \% 4 \mathrm{HB})$ will be higher compared to $\mathrm{P}(3 \mathrm{HB}-\mathrm{co}-25 \mathrm{~mol} \%$ 4HB). Control in this study showed no weight loss when immersed in phosphate buffer without enzyme addition thus indicating no significant hydrolysis by buffer occurred during incubation.

\section{Environmental degradation}

PHAs have very high molecular weight and very difficult to be transported into the cells. Therefore, microorganisms have to excrete extracellular PHA depolymerase to degrade the extracellular PHA. The solid PHA can then be hydrolysed into water soluble oligomers and monomer which will be subsequently utilized by the PHA degrading microorganisms (Reddy et al., 2008). According to Mukai \& Doi (1993), PHA degrading microorganisms can be isolated from various environments such as soil (Pseudomonas lemoignei), activated sludge (Alcaligenes faecalis), lab settings (Pseudomonas pickettii), sea water (Comamonas testosterone) and lake water (Pseudomonas stutzeri). In this study, the degradation performance of $\mathrm{P}(3 \mathrm{HB})$ and $\mathrm{P}(3 \mathrm{HB}-\mathrm{co}-4 \mathrm{HB})$ in lake environment (fresh water) was investigated. Liquid environment was 
chosen because the rich microbial population or activity of microorganisms is closely connected to the presence of water. However, non-biotic effects such as irradiation, thermal degradation or chemical hydrolysis also contribute to degradation of PHAs but at a lower rate (Miiller, 2005).

Parameters tested in this study were concentration of PHA and effect of copolymer on degradation. The degradation effects on electrospun films after immersion in lake water were evaluated through SEM studies. $3 \%$ and $4 \% \mathrm{P}(3 \mathrm{HB})$ were electrospun for $15 \mathrm{~min}$ and immersed into the freshwater lake for a week to compare the degradation rate. SEM investigation of electrospun film thereafter revealed that degradation of the electrospun films of $3 \%$ and $4 \% \mathrm{P}(3 \mathrm{HB})$ occurred at the surface by enzymatic hydrolysis. The degradation of $\mathrm{P}(3 \mathrm{HB}-\mathrm{co}-4 \mathrm{HB})$ copolymer began with surface erosion by microorganisms, followed by gradual deterioration to the innermost (Weng et al., 2013). Both films showed signs of degradation as the films were eroded and diatoms were found to remain attaching on polymer (Fig. 14). $3 \% \mathrm{P}(3 \mathrm{HB})$ degraded faster compared to $4 \%$ $\mathrm{P}(3 \mathrm{HB})$ with the assumption that environmental conditions are constant $(\mathrm{pH}$, temperature, water activity, etc.) for both films. Therefore, the effect of substrate concentration on $\mathrm{P}(3 \mathrm{HB})$ degradation exhibited an optimum concentration at $3 \%$. The mechanism of degradation of $\mathrm{P}(3 \mathrm{HB})$ is through ester hydrolysis at the surface. Degradation rate of higher concentration of $\mathrm{P}(3 \mathrm{HB})$ at $4 \%$ did not improved as the depolymerase enzyme secreted by the microbial population was probably already saturated. SEM studies confirmed that $4 \%$ $\mathrm{P}(3 \mathrm{HB})$ was degraded much slower compared to $3 \% \mathrm{P}(3 \mathrm{HB})$.

The second parameter investigated was the degradation of copolymer P(3HB-co4HB) in environmental conditions. Research has shown that the rate of surface erosion is highly dependent on molecular weight, polymer composition, crystallinity and the dominant species of bacteria existing in the environment (Gu, 2003). An assumption was made that extracellular PHA depolymerases and lipases secreted by a wide range of microbial population in the environment can degrade $\mathrm{P}(3 \mathrm{HB}-\mathrm{co}$ 4HB). So, $\mathrm{P}(3 \mathrm{HB}-\mathrm{co}-4 \mathrm{HB})$ should show better degradation compared to $\mathrm{P}(3 \mathrm{HB})$ as $\mathrm{P}(3 \mathrm{HB})$ can only be degraded by PHA depolymerase. Furthermore, microbes prefer to degrade copolymers rather than homopolymer because the
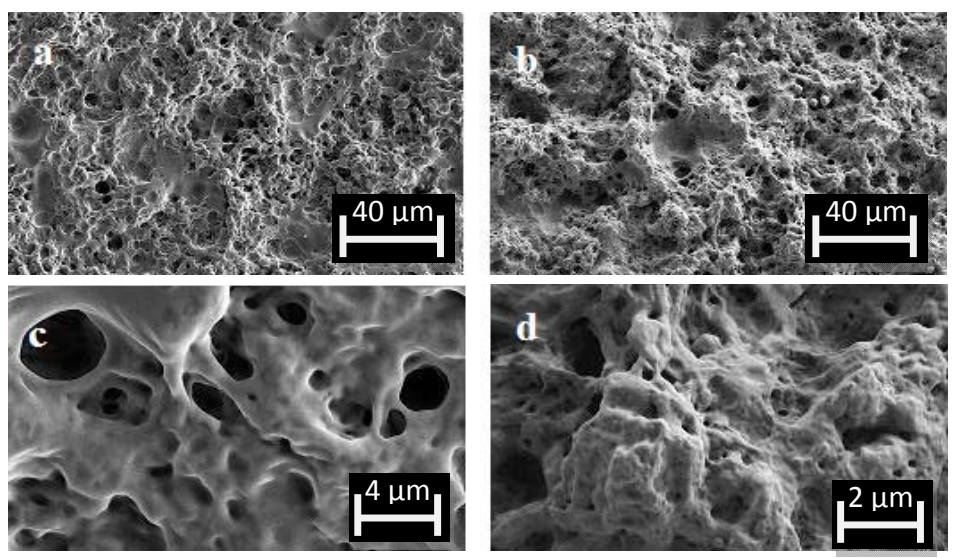

Fig. 14: SEM image of $\mathrm{P}(3 \mathrm{HB}-\mathrm{co}-25 \mathrm{~mol} \%$ 4HB) subjected to degradation by lipase enzyme solution. (a) and (c): $1 \% \mathrm{P}(3 \mathrm{HB}-c o-25 \mathrm{~mol} \% 4 \mathrm{HB})$ before degradation. (b) and (d): $1 \% \mathrm{P}(3 \mathrm{HB}-\mathrm{co}-25 \mathrm{~mol} \% 4 \mathrm{HB})$ after degradation 
highly crystalline structure of homopolymer makes degradation difficult. The copolymers exhibited higher degradation rate could also be due to the steric hindrance presents between carbonyl oxygen atoms of 4HB monomer (Salim et al., 2012). From the SEM study, it was found that the P(3HB-co-75 mol \% 4HB) was rapidly degraded compared to $\mathrm{P}(3 \mathrm{HB}-$ co-25 mol \% 4HB). The presence of high percentages of $4 \mathrm{HB}$ monomers in the $\mathrm{P}(3 \mathrm{HB})$ backbone disrupts the crystalline structure of the homopolymer and increases the amorphous proportion of the polymer structure. A decrease in crystallinity aids in the degradation process as the aquatic environment enzymes secreted by microorganisms preferentially degrade the amorphous part of polymers rather than the crystalline region thereby increasing the degradation rate (Sridewi et al., 2006).

\section{Conclusion}

Fabrication of $\mathrm{P}(3 \mathrm{HB})$ homopolymer using electrospinning technique produced fibers when a voltage of $30 \mathrm{kV}$ was applied to polymer solution which was extruded at a rate of $60 \mu \mathrm{L} / \mathrm{min}$. Preheating of the solution for
15 min at $60{ }^{\circ} \mathrm{C}$ had an added advantage in improving the miscibility and homogeneity of polymer solution prior to electrospinning. Fabricated film of P(3HB-co-25 mol \% 4HB) and $\mathrm{P}(3 \mathrm{HB}-\mathrm{co}-75 \mathrm{~mol} \%$ 4HB) copolymers showed the best degradation rate. SEM studies on the $\mathrm{P}(3 \mathrm{HB})$ and $\mathrm{P}(3 \mathrm{HB}-c o-4 \mathrm{HB})$ revealed that $\mathrm{P}(3 \mathrm{HB})$ exhibited hairy appearances after degradation by PHA depolymerase and $\mathrm{P}(3 \mathrm{HB}-$ co-4HB) became more porous after degradation by lipase enzyme. Degradation of polymer by environmental exposure for 1 week confirmed that microbial activity plays important role in the degradation of $\mathrm{P}(3 \mathrm{HB})$ and $\mathrm{P}(3 \mathrm{HB}-\mathrm{co}$ 4HB). SEM study also revealed the attachment of diatoms on the films; therefore it is possible that these microorganisms also contribute to the disintegration of the polymer films.

\section{Acknowledgement}

This research was supported by the Long Term Research Grant Scheme (LRGS) (203/ PKT/6725001). We are grateful to J. M. M. Tay for her helpful contribution in this research. L. Joyyi would like to thank Universiti Sains Malaysia LRGS for the financial support.

\section{References}

1. Agarwal S., Greiner A., Wendorff J.H. (2013) Functional materials by electrospinning of polymers. Progress in Polymer Science 38(6): 963-991.

2. Amara A.A.A.F. (2008) Polyhydroxyalkanoates: From basic research and molecular biology to application. IUM. Eng. J. 9: 37-73.

3. Cheng M.-L., Lin C.-C., Su H.-L., Chen P.-Y., Sun Y.-M. (2008) Processing and characterization of electrospun poly (3-hydroxybutyrate-co-3-hydroxyhexanoate) nanofibrous membranes. Polymer 49 (2): 546-553.

4. Deitzel J., Kleinmeyer J., Harris D., Tan N.B. (2001) The effect of processing variables on the morphology of electrospun nanofibers and textiles. Polymer 42(1): 261-272.

5. Frenot A., Chronakis I. (2003) Polymer nanofibers assembled by electrospinning. Current Opinion in Colloid \& Interface Science 8(1): 64-75.

6. Griffith L.G. (2002) Emerging design principles in biomaterials and scaffolds for tissue engineering. Annals of New York Academy of Sciences 961 (Reparative Medicine: Growing Tissues and Organs) 83-95. 
7. Gu J.-D. (2003) Microbiological deterioration and degradation of synthetic polymeric materials: recent research advances. International Biodeterioration \& Biodegradation 52(2): 69-91.

8. Hsieh W.-C., Mitomo H., Kasuya K.-i., Komoto T. (2006) Enzymatic degradation and aminolysis of microbial poly (3-hydroxybutyrate-co-4-hydroxybutyrate) single crystals. Journal of Polymers and the Environment 14(1): 79-87.

9. Jendrossek D., Handrick R. (2002) Microbial degradation of Polyhydroxyalkanoates. Annual Reviews in Microbiology 56(1): 403-432.

10. Kasuya K., Inoue Y., Doi Y. (1996) Adsorption kinetics of bacterial PHB depolymerase on the surface of polyhydroxyalkanoate films. International Journal of Biological Macromolecules 19(1): $35-40$.

11. Lemoigne M. (1926) Produits de dehydration et de polymerisation de l' acide ß-oxobutyrique. Bull Soc Chim Biol 8: 770-782.

12. Li X.-T., Zhang Y., Chen G.-Q. (2008) Nanofibrous polyhydroxyalkanoate matrices as cell growth supporting materials. Biomaterials 29(27): 3720-3728.

13. Li Z., Lin H., Ishii N., Chen G.-Q., Inoue Y. (2007) Study of enzymatic degradation of microbial copolyesters consisting of 3-hydroxybutyrate and medium-chain-length 3-hydroxyalkanoates. Polymer Degradation and Stability 92(9): 1708-1714.

14. Mergaert J., Ruffieux K., Bourban C., Storms V., Wagemans W., Wintermantel E., Swings J. (2000) In vitro biodegradation of polyester-based plastic materials by selected bacterial cultures. Journal of Polymers and the Environment 8(1): 17-27.

15. Miiller R.-J. (2005) Biodegradation Behaviour of Polymers in Liquid Environments. In: Bastioli C. (ed.) Handbook of Biodegradable Polymers. Shrewsbury, UK: Rapra Technology Limited, p. $33-42$.

16. Mitomo H., Hsieh W.-C., Nishiwaki K., Kasuya K., Doi Y. (2001) Poly (3-hydroxybutyrate-co-4hydroxybutyrate) produced by Comamonas acidovorans. Polymer 42(8): 3455-3461.

17. Nelson T., Kaufman E., Kline J., Sokoloff L. (1981) The Extraneural Distribution of $\square$-Hydroxybutyrate. Journal of Neurochemistry 37(5): 1345-1348.

18. Ren J., Liu W., Zhu J., Gu S. (2008) Preparation and characterization of electrospun, biodegradable membranes. Journal of Applied Polymer Science 109(5): 3390-3397.

19. Salim Y.S., Sharon A., Vigneswari S., Ibrahim M.N.M., Amirul A.A. (2012) Environmental degradation of microbial polyhydroxyalkanoates and oil palm-based composites. Applied Biochemistry and Biotechnology 167(2): 314-326.

20. Sridewi N., Bhubalan K., Sudesh K. (2006) Degradation of commercially important polyhydroxyalkanoates in tropical mangrove ecosystem. Polymer Degradation and Stability 91(12): 2931-2940.

21. Sudesh K., Abe H., Doi Y. (2000) Synthesis, structure and properties of polyhydroxyalkanoates: biological polyesters. Progress in Polymer Science 25(10): 1503-1555.

22. Tan I.K. (2006) Polyhydroxyalkanoates. In: A. Siedel (Ed.) Kirk-Othmer Encyclopedia of Chemical Technology 20. New Jersey: John Wiley \& Sons, Inc. Hoboken, p. 249-264.

23. Tokiwa Y., Calabia B.P. (2004) Review degradation of microbial polyesters. Biotechnology Letters 26(15): 1181-1189. 
24. Wang C., Hsu C.-H., Hwang I.-H. (2008) Scaling laws and internal structure for characterizing electrospun poly [(R)-3-hydroxybutyrate] fibers. Polymer 49(19): 4188-4195.

25. Wang X., Ding B., Sun G., Wang M., Yu J. (2013) Electro-spinning/netting: a strategy for the fabrication of three-dimensional polymer nano-fiber/nets. Progress in Materials Science 58(8): $1173-1243$.

26. Weng Y.-X., Wang L., Zhang M., Wang X.-L., Wang Y.-Z. (2013) Biodegradation behavior of $\mathrm{P}(3 \mathrm{HB}, 4 \mathrm{HB}) / \mathrm{PLA}$ blends in real soil environments. Polymer Testing 32(1): 60-70.

27. Zhao Q., Cheng G. (2006) The degradation mechanisms of PHB and degradation behaviour of PHB/PEG derivatives. New Frontiers in Polymer Research: pp. 111-116. 